\title{
Morfologia do epidídimo de cobaio (Cavia porcellus) em diferentes fases do desenvolvimento pós-natal
}

\author{
Morphological differentiation of the epididymis of guinea pig (Cavia porcellus) at different \\ ages
}

\author{
Bruno Cesar SCHIMMINGㅁ; Raquel Fantin DOMENICONI ${ }^{1}$; Maria do Carmo PANHOZA TSE²; Hero \\ Gondinho TSE ${ }^{2,3}$; Antonio Marcos ORSI ${ }^{1,3}$
}

\author{
${ }^{1}$ Departamento de Anatomia do Instituto de Biociências da Universidade Estadual Paulista, Botucatu-SP, Brasil \\ ${ }^{2}$ Departamento de Morfologia do Instituto de Biociências da Universidade Estadual Paulista, Botucatu-SP, Brasil \\ ${ }^{3}$ Faculdade de Medicina e Enfermagem da Universidade de Marília, Marília-SP, Brasil
}

\begin{abstract}
Resumo
A evolução morfológica do ducto epididimário de cobaio (Cavia porcellus, L.) foi avaliada nas faixas etárias de 10, 20, 30, 45,60, 70, 90 e 100 dias após o nascimento, mostrando-se complexa, o que é decorrente da própria diferenciação pós-natal do epitélio epididimário. Assim sendo, o segmento inicial epididimário mostrou um aumento de altura epitelial correspondente aos valores médios de alturas das células principais do epitélio tubular, crescente após 45 dias de idade pós-natal. As alturas epiteliais obtidas em nível do segmento médio foram maiores em idades juvenis (de $10 \mathrm{a}$ 45 dias) do que na idade pré-puberal (60 dias), tendo diminuído entre os 70 e 100 dias de idade. No segmento terminal epididimário, verificou-se um decréscimo marcante da altura epitelial tubular a partir da idade puberal (70 dias) até a idade adulta (a partir de 90 dias). Além disso, este segmento apresentou ondulações epiteliais que cessaram aos 70 dias de idade, momento em que a luz tubular se preenche com espermatozoides e esfoliações celulares. Os tipos celulares do epitélio tubular epididimário, células principais, basais e apicais, foram observados em todas as idades. Em epidídimos de animais muito jovens, observou-se a predominância de células colunares indiferenciadas. A partir de 20 dias de idade, houve prevalência natural das células principais sobre os demais tipos celulares, como é peculiar ao epitélio epididimário de mamíferos, de modo geral.
\end{abstract}

Palavras-chave: Epitélio epididimário. Desenvolvimento pós-natal. Morfologia. Cobaio.

\begin{abstract}
The morphological evolution of the epididymal duct of guinea pigs (Cavia porcellus, L.) was studied on 10, 20, 30, 45, 60, 70, 90 and 100 days of age, being complex, which is due to the proper differentiation postnatal in the epididymal epithelium. Thus, it was observed that the initial segment of the epididymis reveals an increase of epithelial height corresponding to the average height of the main tubular epithelium cells, generally progressive after 45 days of age. The epithelial height in the middle segment were higher in younger stages (10 to 45 days) than in the prepubertal age (60 days), and have a decrease among 70 to 100 days of age. The ductular terminal segment starts a gradual decrease of the epithelial heights from puberal age (70 days), until adult age (90 to 100 days). In addition, this segment showed epithelial waviness that disappeared after 70 days of age, when the lumen fills it with sperm and cellular exfoliation. The cell types of the epididymal tubular epithelium, principal cells, basal cells and apical cells, were observed in all ages. In the epididymis of very young animals, there was a predominance of undifferentiated columnar cells. After 20 days of age, there was natural prevalence of the principal cells on other cell types, what is a feature similar to other mammals.
\end{abstract}

Keywords: Epididymal epithelium. Postnatal development. Morphology. Guinea pig.

\section{Introdução}

O epidídimo de cobaio, um roedor cavídeo sul-americano, é anatomicamente complexo, em decorrência do adelgaçamento marcante do segmento inicial e do corpo epididimários e do alargamento da cauda deste órgão $o^{1,2}$. Histologicamente, foram identificadas sete zonas epididimárias definidas, tanto na espécie laboratorial Cavia porcellus ${ }^{3,4}$, como em espécies sil-

\section{Correspondência para:}

Bruno Cesar Schimming

Departamento de Anatomia

Instituto de Biociências de Botucatu, UNESP

Cx. Postal, 510, Distrito de Rubião Júnior

CEP.: 18618-970, Botucatu, SP, Brasil

e-mail: bruno@ibb.unesp.br

Recebido: 03/08/2011

Aprovado: 15/08/2012 
vestres $^{2}$. No epidídimo das espécies Cavia porcellus e Galea musteloides (cavídeo silvestre), destacam-se as regiões anatômicas do segmento inicial (zona histológica I); duas regiões, proximal e distal, da cabeça epididimária (zonas histológicas II e III, respectivamente); a região anatômica do corpo epididimário (zona histológica IV), e três regiões, proximal, média e distal da cauda epididimária (zonas histológicas V, VI e VII, respectivamente) $)^{2}$.

Enfocando principalmente a maturação de espermatozoides epididimários em cavídeos, foi verificado em Galea musteloides, que os espermatozoides adquirem maturação (ou habilidade de fertilização) nas partes mais proximais do compartimento luminal epididimário. Por outro lado, em Cavia aperea, a maturação dos espermatozoides se verifica na parte mais distal (regiões da cauda), do compartimento luminal epididimário $^{2}$. A maturação dos espermatozoides na parte tubular epididimária mais distal da Cavia porcellus, similarmente à de Cavia aperea, também foi sugerida ${ }^{4}$.

A morfologia epididimária encontrada em Cavia aperea e Cavia porcellus é bastante semelhante ${ }^{2}$. Sabe-se que em Cavia porcellus, com base na evolução morfológica do epitélio seminífero, a puberdade é assumida aos 70 dias de idade pós-natal, estando os machos na condição de adultos jovens aos 90 dias de idade $^{5}$. Contudo, em nenhuma das espécies de cavídeos citadas, houve qualquer enfoque relativo à diferenciação morfológica pós-natal do ducto epididimário, objetivo deste estudo em Cavia porcellus.

Em outros roedores como o rato e o hamster, a diferenciação do epitélio epididimário pós-natal ocorre a partir dos 10 dias de idade, quando a célula colunar indiferenciada começa a atuar como células-tronco (stem cells), originando os tipos da linhagem celular epididimária ${ }^{6,7,8,9,10,11}$.

A população do epitélio epididimário em cobaios adultos é caracterizada, principalmente, pelas células principais, basais e apicais, havendo amplo predomínio das células principais sobre os demais tipos celulares ${ }^{4}$. Os papéis funcionais atribuídos às células principais epididimárias compreendem a endocitose de fase fluida (pinocitose) e a endocitose adsorptiva (fagocitose); absorção de fluidos e pequenos solutos e secreção de íons salinos e macromoléculas, com destaques para proteínas e glicoproteínas ${ }^{11,12,13,14,15,16,17,18,19}$. As células apicais são morfologicamente aparentadas às células principais ${ }^{7}$ e foram inicialmente estudadas no segmento inicial. Este tipo celular está localizado no ápice do epitélio epididimário, contendo muitas enzimas proteolíticas e podendo ter papel na proteção dos espermatozoides a ataques eletrofílicos ${ }^{20}$. Às células basais têm sido atribuídos papéis controversos, que vão desde a estabilização morfofuncional do epitélio epididimário ${ }^{21}$, até a atuação como possíveis células-tronco das células epiteliais epididimárias ${ }^{17}$. Em estudos realizados com células basais de epidídimo humano, concluiu-se que existem similaridades ultraestrutural, antigênica e espacial entre as células basais e os macrófagos ${ }^{22}$. Com base nestes achados, os autores propõem a hipótese que os macrófagos são precursores das células basais, provendo um lento turnover desta população celular, que se tornariam sobrecarregadas com os detritos removidos do epitélio, o que ressalta a possível importância do epidídimo nos aspectos imunológicos da fertilidade.

Em face dos embasamentos teóricos apresentados, este trabalho objetiva analisar as características morfológicas e a diferenciação celular, em diferentes fases do desenvolvimento pós-natal, do ducto epididimário de cobaio, Cavia porcellus, um roedor de largo emprego laboratorial, utilizado como animal de companhia e também como fonte alimentar de alguns povos andinos ${ }^{1}$.

\section{Material e Método}

Neste trabalho, foram utilizados epidídimos coletados de 24 cobaios, Cavia porcellus, sendo cada três cobaios de oito faixas etárias distintas de 10, 20, 30, $45,60,70,90$ e 100 dias, respectivamente. Os roedores 
foram obtidos a partir de linhagens albinas e endogâmicas criadas em cativeiro no Biotério Central da Universidade Estadual Paulista, Campus de Botucatu, São Paulo, Brasil. Após o desmame, os animais foram mantidos no Biotério do Departamento de Anatomia do Instituto de Biociências da Universidade Estadual Paulista, campus de Botucatu, até atingirem as idades estipuladas para eutanásia e coleta dos epidídimos, exceto os primeiros grupos que foram retirados da mãe antes do desmame. Três cobaios de cada grupo foram eutanasiados com doses elevadas de cetamina (20mg/kg) (Quetamina', Vetnil, Louveira, São Paulo, Brasil) e xilazina (1,5mg/kg) (Virbaxyl', Virbac, São Paulo, Brasil). A adoção das faixas etárias estipuladas entre 10 e 100 dias de idade, se fez com base na evolução testicular nestas mesmas faixas de idades, que possibilitou determinar, para o cobaio, períodos juvenis (20 e 30 dias), pré-puberais ( 45 e 60 dias), puberal (70 dias) e pós-puberais (90 e 100 dias) ${ }^{5}$.

Os epidídimos foram coletados imediatamente após eutanásia dos cobaios, através de laparotomia mediana, realizada na região púbica, com a migração dos órgãos para a cavidade abdominal por meio do trajeto inguinal pérvio nestes roedores ${ }^{1}$. O material biológico foi pré-fixado, por gotejamento constante de formaldeído tamponado $\mathrm{pH}$ 7,4 e dissecado, quando necessário sob microscópio estereoscópico (Olympus SZ, Olympus, Japão) (Departamento de Anatomia, IBB, UNESP, Botucatu, São Paulo, Brasil). Após, os epidídimos foram seccionados nos três segmentos morfofuncionais propostos para o epidídimo de mamíferos: inicial, médio e terminal ${ }^{23}$. Estes segmentos correspondem às seguintes regiões ou zonas histológicas já descritas para o cobaio: o segmento inicial corresponde à zona histológica I, o segmento médio à zona histológica IV e o segmento terminal à zona histológica $\mathrm{VI}^{2,3,4}$.

Posteriormente, o material foi pós-fixado por imersão na solução fixadora overnight e à temperatura ambiente. Os fragmentos dos segmentos epididimários foram processados segundo rotina histológica para microscopia de luz, obtendo-se cortes histológicos de $5 \mu \mathrm{m}$, corados com HE e tricrômico de Masson, os quais foram destinados para estudos morfológicos e morfométricos das alturas do epitélio tubular epididimário nas diferentes idades estudadas.

O estudo morfométrico dos epidídimos foi realizado em idades de 10, 20, 30, 45, 60, 70, 90 e 100 dias. Este estudo procedeu-se em termos de medições das alturas do epitélio epididimário (em $\mu \mathrm{m})$, nos diferentes segmentos epididimários e nas diferentes idades. Ressalta-se que as alturas médias epiteliais epididimárias representam as alturas das células principais. O citoplasma destas células se estende desde a membrana basal até o lúmen tubular, que orlam uniformemente através da borda apical, dotada de estereocílios. Para as mensurações das alturas do epitélio epididimário, foram utilizadas três lâminas de cada animal, em cada faixa etária; contendo estas, seis cortes histológicos com quatro medidas feitos por corte. Para tanto, utilizaram-se os recursos de um sistema integrado de análise de imagens, formado por um microscópio de pesquisa (Olympus BX-40, Olympus, Japão) (Departamento de Anatomia, IBB, UNESP, Botucatu, São Paulo, Brasil) e um Software System Media Cybernetics (EUA).

\section{Resultados}

O epitélio epididimário indiferenciado, observado em idades muito jovens (10 dias), se caracteriza pela presença dominante de células colunares indiferenciadas (Figura 1A), que depois são substituídas pelas células principais. Estas são elementos celulares cilíndricos, normalmente dominantes, em termos numéricos e citofisiológicos, no epidídimo do cobaio. De forma notável, estas células colunares indiferenciadas são observadas no segmento terminal aos 20 dias (Figura 1D), notadas, contudo, de permeio a algumas células principais com morfologia nuclear típica. Ao que parece, o segmento terminal aos 20 dias é relati- 

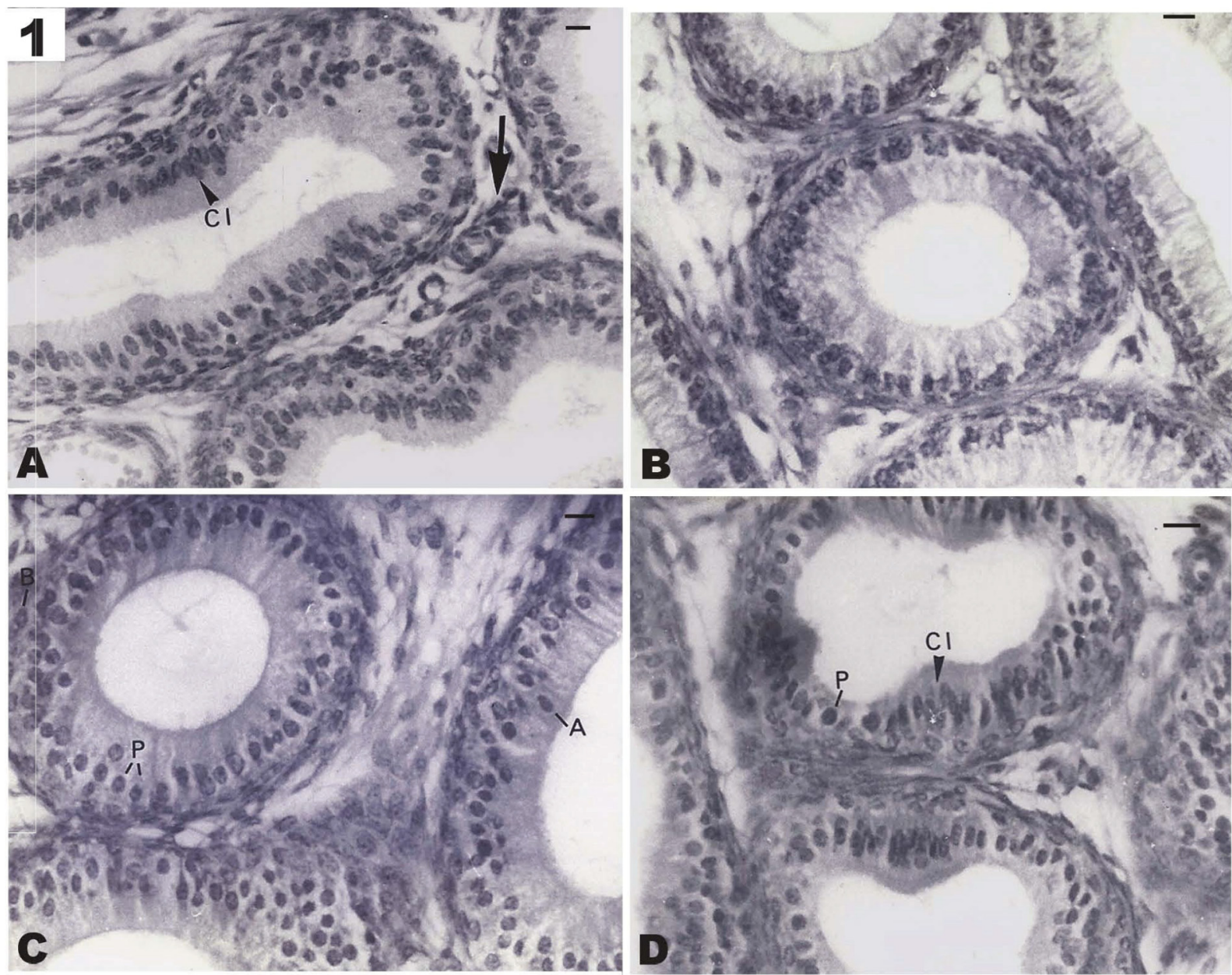

Figura 1 - Segmento terminal do epidídimo do cobaio aos 10 dias de idade em a, segmento inicial aos 20 dias de idade em $\underline{\mathbf{b}}$, segmento médio aos 20 dias em $\underline{\mathbf{c}}$, e segmento terminal aos 20 dias de idade em $\underline{\mathbf{d}}$. São indicadas células principais $(\mathrm{P})$, apicais $(\mathrm{A})$, células colunares indiferenciadas $(\mathrm{CI})$ e aglomerado vascular (seta) presente no interstício tubular. Barra $=1 \mu \mathrm{m}$

vamente menos diferenciado que os segmentos precedentes nesta mesma idade.

Aos 20 dias de idade, nos segmentos inicial e médio do epidídimo do cobaio, já se observa uma relativa diferenciação das células do epitélio de revestimento, caracterizando-se células principais, basais e apicais, especialmente, no segmento médio (Figuras 1B e C). Contudo, no segmento terminal, o epitélio de revestimento tubular retém algumas características morfológicas do epitélio epididimário indiferenciado, observado aos 10 dias (Figuras 1A e D). Nos segmentos inicial e terminal, a partir de 45 dias, já se nota que a população celular epididimária no cobaio consiste, basicamente, de células principais, basais e apicais (Figuras 2B e A), ao passo que, no segmento médio, o mesmo já pode ser observado a partir de 30 dias (Figura 3A).

No segmento inicial em idades jovens, até 30 dias, nota-se também uma certa ondulação no epitélio de revestimento, que ainda é muito baixo, porém, sendo mais discreta do que as observadas no segmento terminal até os 60 dias. Aos 45 dias, o epitélio do segmento inicial se diferencia de forma notável, se aproximando em termos morfológicos da aparência usual que se verifica neste segmento no animal puberal (70 dias) e no animal adulto (Figuras 2A, B, C e D), o 

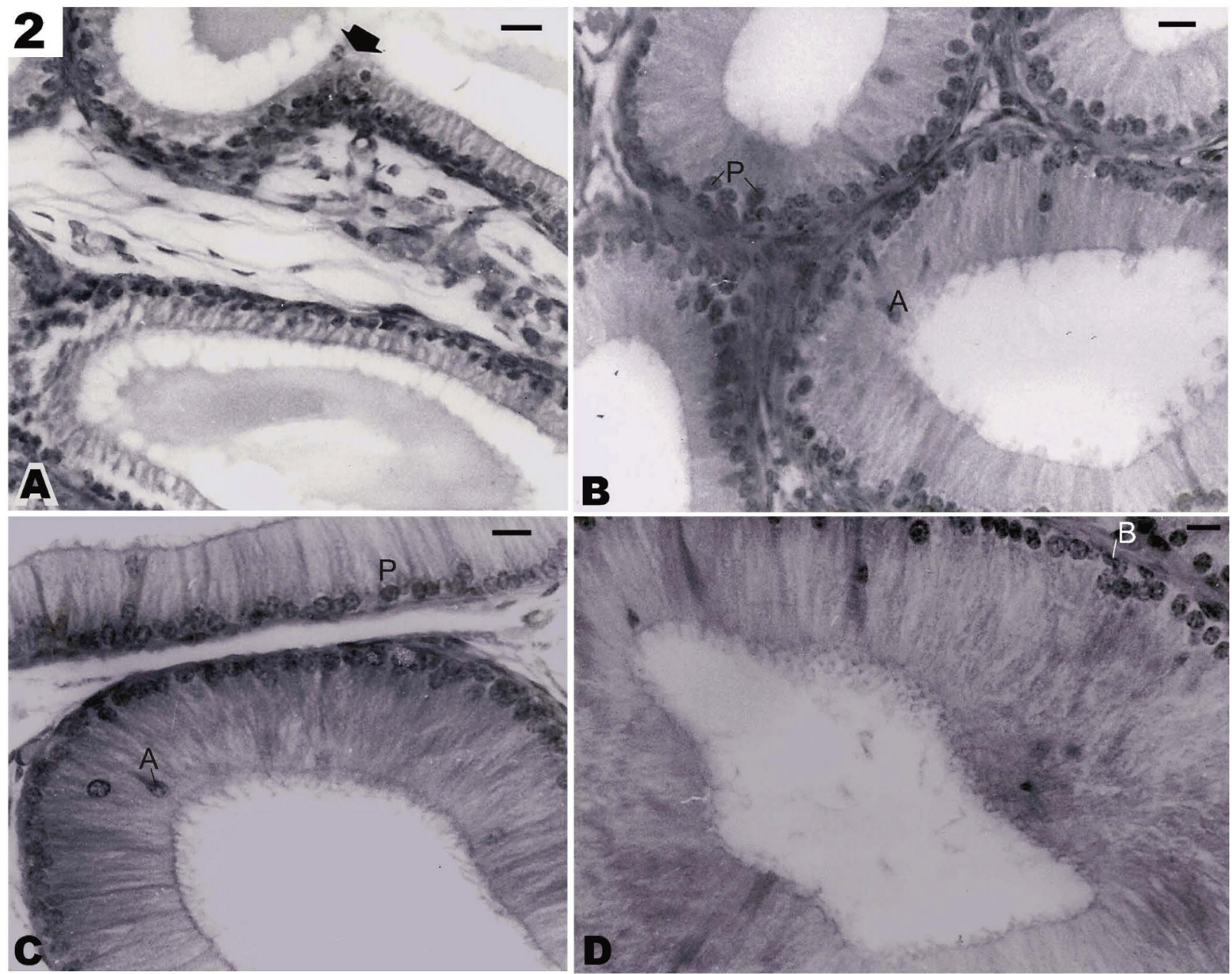

Figura 2 - Segmento inicial do epidídimo do cobaio. São apontadas ondulação (seta) e menor altura do epitélio de revestimento aos 30 dias de idade em $\underline{\mathbf{a}}$. Em $\underline{\mathbf{b}}$, notar o aumento da altura do epitélio de revestimento aos 45 dias de idade e em $\mathbf{c}$ e $\mathbf{d}$, observar células principais (P), basais (B) e apicais (A), o epitélio elevado e o contorno irregular da luz tubular, respectivamente, aos 70 e 100 dias de idade. Barra $=1 \mu \mathrm{m}$

que equivale dizer que o epitélio se torna muito alto, com os núcleos das células principais se dispondo basalmente. O citoplasma apical destas células é uma grande faixa homogeneamente eosinófila. A borda luminal das células principais apresenta estereocílios conspícuos e a luz tubular é irregular e, às vezes, estrelada (Figuras 2C e D).

Histologicamente, o segmento médio, em todas as idades estudadas, é o de maior regularidade epitelial, mesmo em etapas juvenis ou pré-puberais. Este segmento apresenta inclusive certa constância morfológica em termos do epitélio de revestimento em todas as idades estudadas. O epitélio não varia muito a sua altura média com o evolver da idade, embora esta altura diminua um pouco nos epidídimos de cobaios adultos, inclusive não se observando ondulações epiteliais (Figuras 3A, B, C e D).

O conteúdo luminal do segmento médio apresenta variações nas diferentes idades, que aparentemente acompanham a evolução cronológica do desenvolvimento testicular. Assim, aos 20 e 30 dias, a sua luz está vazia, nas diferentes secções de corte do ducto (Figura $3 \mathrm{~A})$. Aos 45 e 60 dias, o conteúdo luminal do segmento médio é representado por material formado por esfoliações celulares (Figuras 3B e C). Enfim, a partir dos 70 dias, com observações constantes aos 90 dias e 

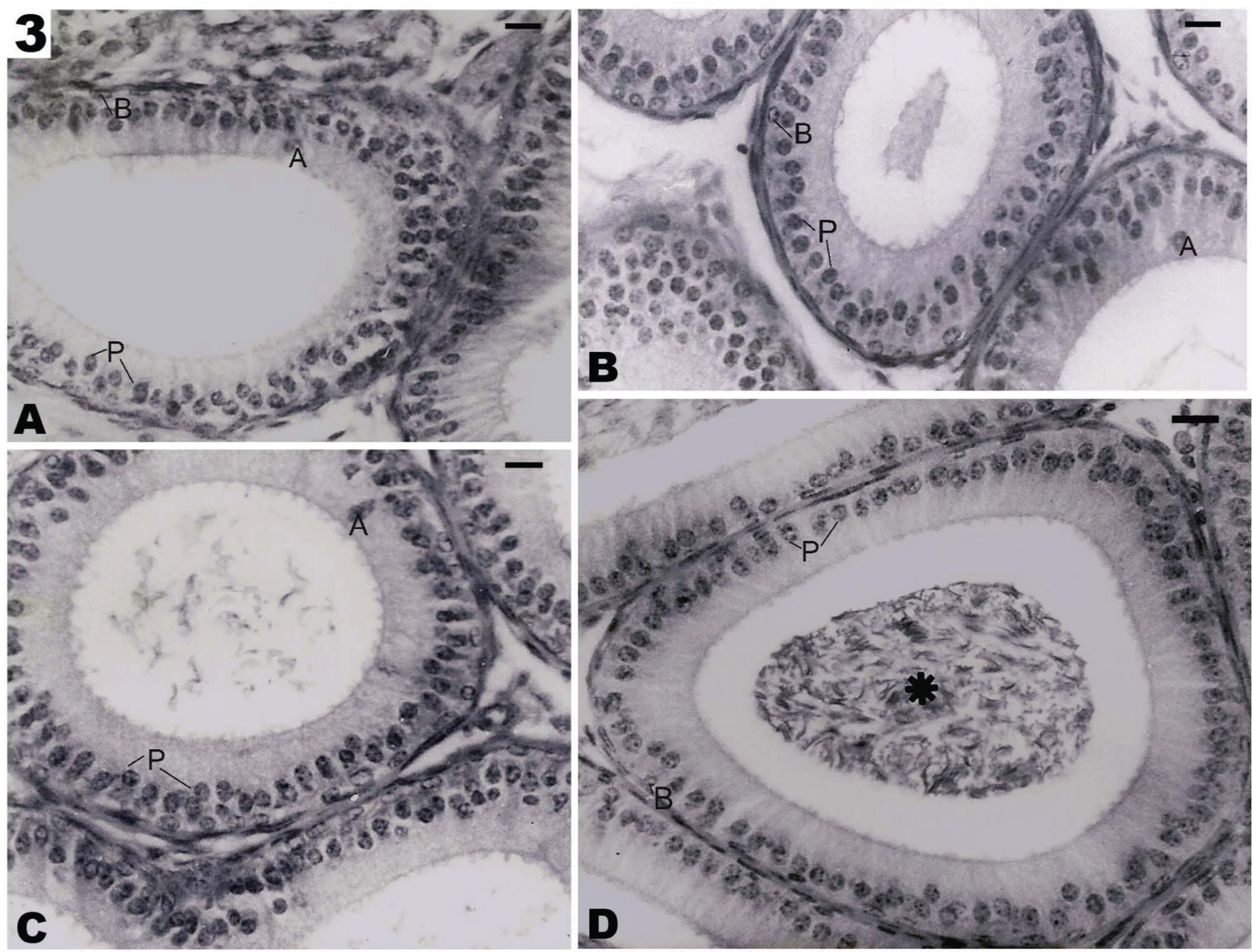

Figura 3 - Segmento médio do epidídimo do cobaio. Observar a regularidade de diferenciação epitelial e a constância morfológica do epitélio tubular aos 30 dias em $\underline{\mathbf{a}}$, aos 45 dias em $\underline{\mathbf{b}}$, aos 60 dias em $\underline{\mathbf{c}}$, e aos 80 dias em $\underline{\mathbf{d}}$. São indicados o conteúdo luminal com espermatozoides (asterisco), células principais (P), basais (B) e apicais (A). Barra $=1 \mu \mathrm{m}$

a partir desta idade, a luz tubular da maior parte das secções transversais neste segmento, se acha preenchida de esfoliado celular, além de grande número de espermatozoides (Figura 3D).

O segmento terminal apresenta outra característica morfológica da indiferenciação, além das células colunares indiferenciadas, que é a presença de ondulações do epitélio. Estas formações epiteliais notoriamente persistem no segmento terminal epididimário aos 45 dias e se mantêm no mesmo segmento aos 60 dias. A característica de ondulamento epitelial do epitélio epididimário no segmento terminal cessa aos 70 dias, quando a luz tubular se preenche com espermatozoides, "espermiados" em nível testicular (Figuras 4A, B e C).
Aos 70 dias de idade, o interstício tubular no segmento terminal continua a ser predominantemente formado de tecido conjuntivo frouxo. Porém, na parte mais distal deste segmento, que tende ao ducto deferente, é substituído por matriz mioconjuntiva. Acrescentam-se, aos elementos celulares do tecido conjuntivo, fibras musculares lisas e maior quantidade de fibras colágenas. Este padrão é repetitivo à parte distal do segmento terminal, no epidídimo de animais adultos, a partir de 90 dias de idade, já que se configura no grande reservatório de espermatozoides pré-ejaculados (Figuras 4C e D).

Quanto ao estudo morfométrico, este foi realizado em todas as faixas etárias já mencionadas e observou- 

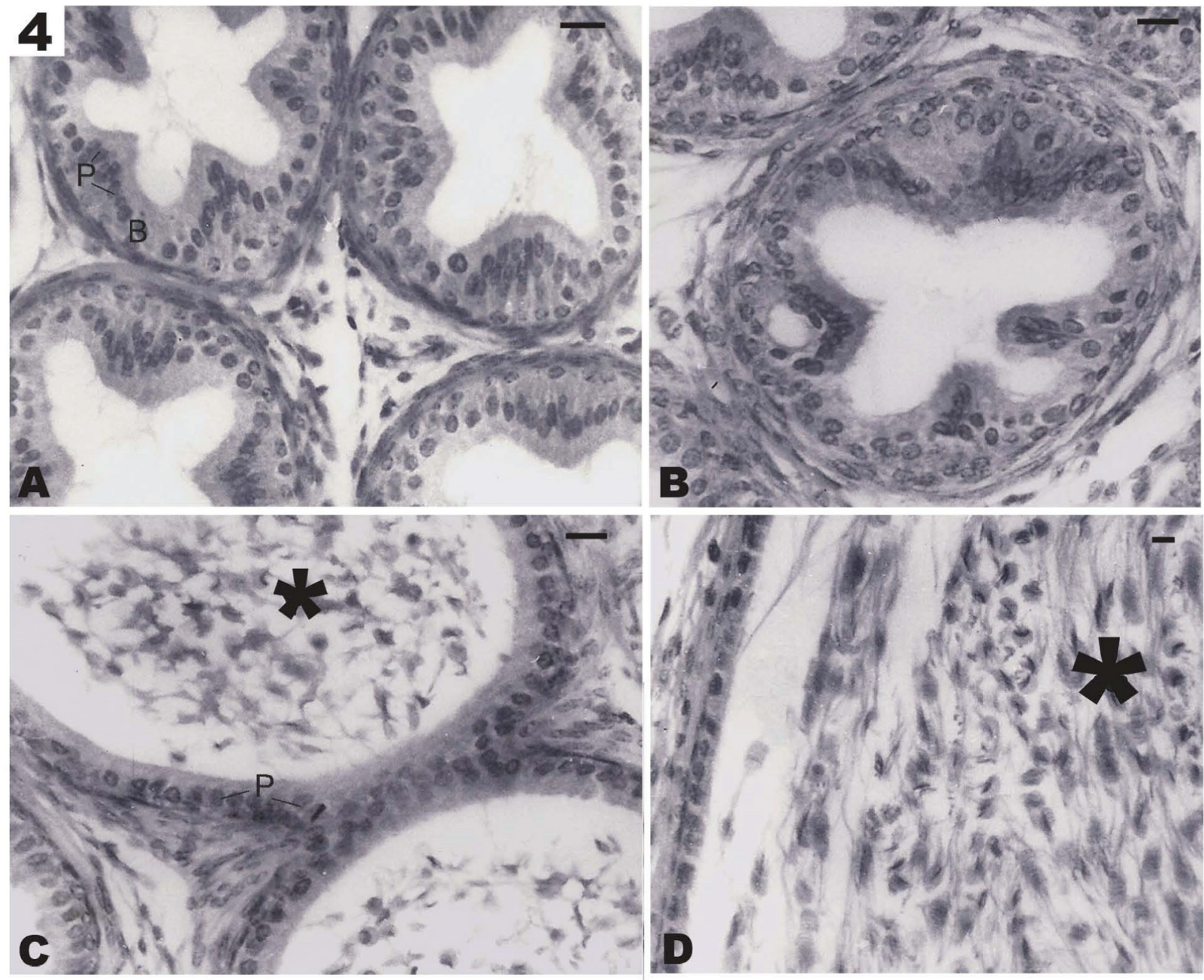

Figura 4 - Segmento terminal epididimário no cobaio aos 45 dias (a), 60 dias (b), 70 dias (c) e 80 dias de idade (d). Notar a ondulação característica do epitélio de revestimento em $\underline{\mathbf{a}} \mathrm{e} \underline{\mathbf{b}}$. São indicados o conteúdo luminal com predomínio de espermatozoides (asterisco), células principais $(\mathrm{P})$ e basais (B). Barra $=1 \mu \mathrm{m}$

-se que a altura epitelial do segmento inicial aumentou com o avançar da idade, sendo maior no animal adulto; já a altura do segmento médio, aumentou até 45 dias de idade e, após, gradativamente, diminuiu. Por outro lado, o segmento terminal, apresentou a maior altura epitelial entre 20 e 45 dias de idade e, após, diminuiu sensivelmente (Figura 5).

\section{Discussão}

O epidídimo nos mamíferos pode ser morfofuncionalmente dividido em três segmentos principais: inicial, médio e terminal, os quais são histológica e funcionalmente definidos, distintos e contínuos entre $\mathrm{si}^{23}$. A morfologia apresentada pelo epidídimo do cobaio nas diferentes idades foi descrita por meio deste modelo segmentar de divisão do ducto, o qual também foi utilizadoa para outros mamíferos, como o rato $^{17,24,25}$, hamster champanha ${ }^{26}$, coelho ${ }^{27}$, gato ${ }^{28}$, rato africano gigante ${ }^{29}$ e equino ${ }^{30}$.

O epitélio de revestimento do ducto epididimário de mamíferos possui uma população celular representada, de maneira geral, pelas células principais, basais e apicais ${ }^{10,30,31,32,33,34}$. Estes tipos celulares foram observados no epidídimo do cobaio a partir dos 20 dias de idade, típicos do epitélio epididimário adulto nesta espécie ${ }^{3,4}$. A diferenciação dos tipos celulares 


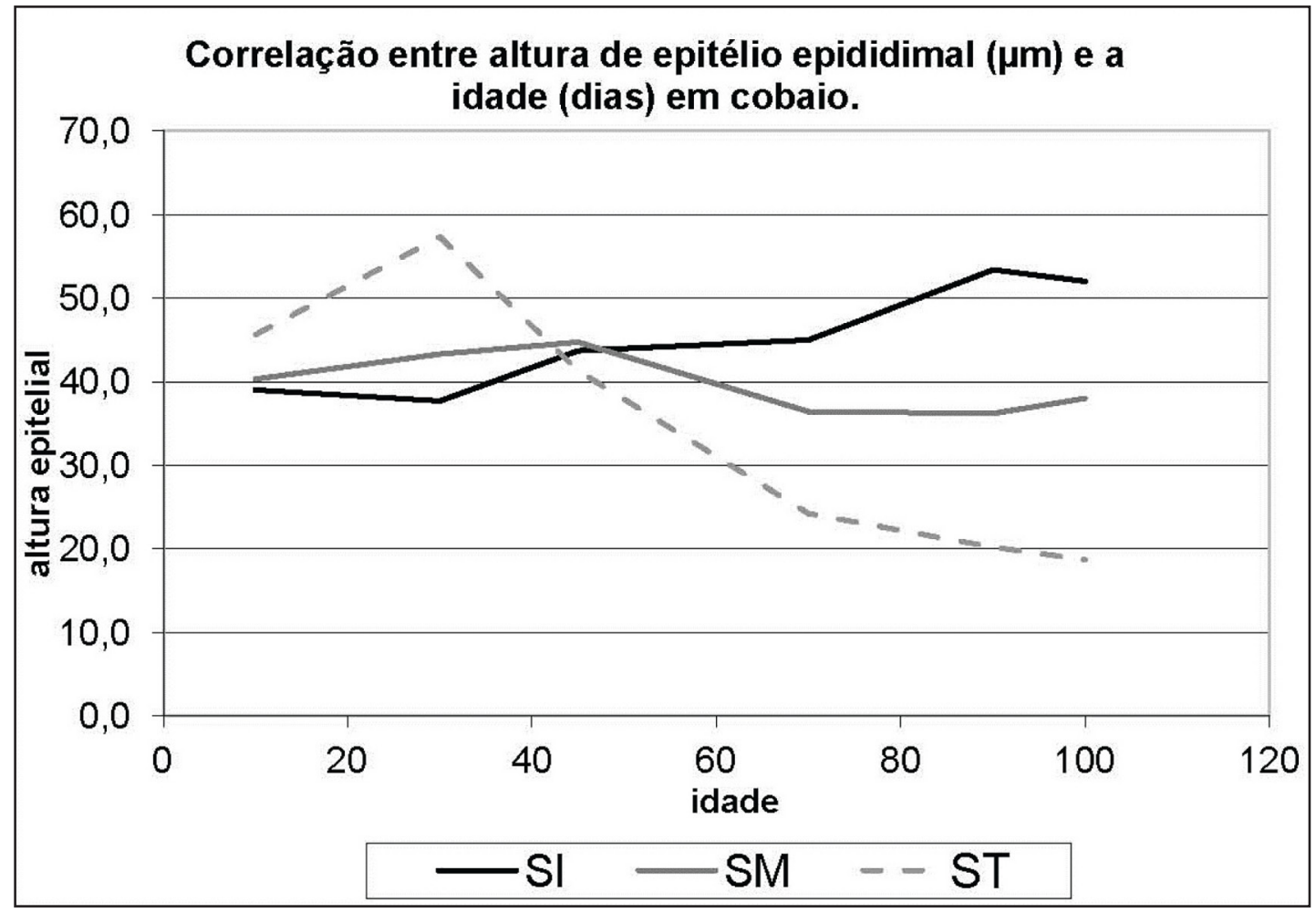

Figura 5 - Correlação entre altura do epitélio epididimário nos segmentos inicial (SI), médio (SM) e terminal (ST) e a idade em cobaios

observados no epitélio epididimário do cobaio se faz a partir das células colunares indiferenciadas, observadas em animais com 10 dias ou mais de idade. Este desenvolvimento parece ocorrer de forma semelhante ao descrito em outros mamíferos ${ }^{6,7,8,9}$.

No epidídimo do cobaio juvenil (10, 20 e 30 dias), do cobaio pré-puberal (45-60 dias) e puberal (70 dias) e do cobaio adulto (a partir de 90 dias), à semelhança do descrito para o hamster ${ }^{9}$, não se observaram outros tipos de células, como células delgadas, claras ou escuras, descritas em outras espécies de mamíferos ${ }^{8,19,28,35}$.

As células principais epididimárias, além das células basais e apicais, parecem se diferenciar, diretamente, a partir das células colunares indiferenciadas ${ }^{6}$. No cobaio aos 10 dias, foram observadas várias células colunares indiferenciadas e, aos 20 dias de idade, notou-se a presença das células principais, basais e apicais e de algumas células colunares indiferenciadas, o que poderia corroborar achados prévios na literatura ${ }^{6}$.
Quanto às flutuações de alturas celulares médias do epitélio epididimário, conforme os resultados deste trabalho, pode-se sugerir que houve efeito da idade na avaliação da altura média do epitélio tubular. No segmento inicial, as alturas epiteliais mostraram-se menores nas três primeiras idades estudadas (10, 20 e 30 dias) quando comparadas aos demais segmentos. Aos 45 dias, verificou-se aumento destas alturas com progressão até os 100 dias, a despeito de ligeiras flutuações, por exemplo, aos 70 dias. Achados semelhantes, relacionados às variações da altura epitelial no segmento inicial, também foram descritos para o hamster ${ }^{9}$.

Os aumentos progressivos da altura média do epitélio epididimário no segmento inicial obedecem a uma tendência natural, uma vez que se mostra o mais alto de todos, no animal adulto. A aparência histológica deste segmento, caracterizada além do epitélio alto, pela presença de luz irregular, desprovida de con- 
teúdo luminal, é peculiar a muitos mamíferos estudados $^{21}$. Sabe-se que este segmento é uma região de trânsito rápido de espermatozoides que se dirigem ao segmento médio e, de secreção de macromoléculas e íons ${ }^{36,37,38}$, embora seja um sítio ativamente metabólico, que realiza processos absortivos e secretórios, a fim de que o espermatozoide inicie o processo maturacional ${ }^{3,24}$.

No segmento médio, as alturas epiteliais epididimárias mostram valores maiores nas idades juvenis (10, 20, 30 e 45 dias). A partir de 45 dias, seus valores relativos diminuem. Esta diminuição epitelial é acompanhada de um aumento relativo, porém não significativo, da luz tubular. Possivelmente, o aumento tubular, acompanhado de relativa diminuição epitelial, observados na idade pré-puberal, se relacionem à função de trânsito dos espermatozoides entre os segmentos proximal e distal do ducto ${ }^{23}$. Além disso, este segmento epididimário é caracterizado como um sítio envolvido na maturação espermática, cujo processo é dependente de secreções específicas do epitélio de revestimento epididimário ${ }^{39}$.

No segmento terminal, apesar de certa oscilação dos valores das alturas epiteliais médias, entre $10 \mathrm{e}$ 60 dias, a partir da idade puberal (70 dias), se verifica diminuição gradual e progressiva da altura epitelial. Esta é acompanhada de um aumento marcante da luz tubular. Observação semelhante foi feita no hamster ${ }^{9}$, onde estas flutuações de alturas epiteliais no segmento terminal no período pré-puberal, talvez, se relacionem à sua necessidade futura de expansão tubular, puberal e pós-puberal, com objetivo de se tornar um reservatório de espermatozoides, o que se traduz na principal função desempenhada pelo segmento terminal do epidídimo de mamíferos.
Este segmento no epidídimo do cobaio também se caracterizou pela presença de ondulações epiteliais que persistiram aos 45 e 60 dias e desaparecem aos 70 dias. Ondulações semelhantes foram observadas no segmento terminal aos 30 e 40 dias e, no segmento proximal aos 20 dias de idade no epidídimo do hamster 9 . O significado funcional destas ondulações ainda permanece incerto, porém, no desenvolvimento pós-natal do epidídimo do rato, os autores atribuem a presença destas ondulações à contração da musculatura lisa e o colapso do lúmen do ducto vazio. Estas ondulações desaparecem quando os espermatozoides são produzidos e enchem a luz tubular ${ }^{6}$. Tal teoria poderia corroborar e explicar nossos achados, já que as ondulações desaparecem no cobaio aos 70 dias de idade, quando estão na puberdade e, os espermatozoides passam a serem produzidos e aparecem no interior do ducto epididimário.

Quanto ao estroma epididimário do cobaio, representado pelo interstício tubular e pelos arranjos de fibrilas colágenas e de células dispostas ao redor das secções transversais do ducto, observa-se maior diferenciação na idade puberal (aos 70 dias). Isto inclusive, com referência à constituição da matriz mioconjuntiva peritubular do segmento terminal. Estas observações recordam aquelas feitas em mamíferos domésticos, com ênfase à idade puberal ${ }^{8,9,35}$.

\section{Conclusão}

As características morfológicas do epidídimo do cobaio, ao longo do desenvolvimento, são semelhantes às observadas em outros roedores, resguardando características específicas relacionadas à diferenciação celular e aos tipos celulares observados no epitélio epididimário.

\section{Referências}

1. COOPER, G.; SCHILLER, A. L. Anatomy of the guinea pig. Cambridge: Harvard University Press, 1975. 417 p.

2.COOPER, T. G.; WEYDERT, S.; YEUNG, C. H.; KUNZL, C.; SACHSER, N. Maturation of epididymal spermatozoa 
in the nondomesticated guinea pigs Cavia aperea and Galea musteloides. Journal of Andrology, v. 21, n. 1, p. 154-163, 2000.

3. HOOFER, A. P.; GREENBERG, J. The structure of the epididymis, efferent ductules and ductus deferens of the guinea pig: a light microscopic study. Anatomical Record, v. 190, n. 3, p. 659-678, 1978.

4. GREENBERG, J.; FORSSMAN, W. G. Studies of the guine pig epididymis. I. Ultrastructure and quantitative morphology of the principal cells. Anatomy and Embryology, v. 168, n. 2, p. 173-194, 1983.

5. PANHOZA-TSE, M. C.; ORSI, A. M. Evolução morfológica do epitélio seminífero na cobaia (Cavia porcellus, L.), entre 10 e 90 dias de idade. Revista Brasileira de Biologia, v. 56, n. 2, p. 223-230, 1996

6.SUN, E. L.; FLICKINGER, C. J. Development of cell types and of regional differences in the postnatal rat epididymis. American Journal of Anatomy, v. 154, n. 1, p. 27-36, 1979.

7. SUN, E. L.; FLICKINGER, C. J. Proliferative activity in the rat epididymis during postnatal development. Anatomical Record, v. 203, n. 2, p. 273-284, 1982.

8. ORSI, A. M.; VICENTINI, C. A.; SEULLNER, G.; CAMILLI, J. A. Observações sobre a diferenciação pós-natal do epitélio epididimário no porco landrace, em diferentes idades. Acta Biológica Leopoldensia, v. 7, p. 35-41, 1985.

9. VICENTINI, C. A.; ORSI, A. M.; BOARO MARTINS, M. R. F. Considerações sobre o desenvolvimento pós-natal do epidídimo do hamster (Mesocricetus auratus). Naturalia, v. 15, p. 35-45, 1990

10.ORSI, A. M.; VIOTTO, M. J. S.; SILVA, T. P.; GOMES, E. R. C. Histologia regional e desenvolvimento pós-natal do epidídimo do camundongo negro isogênico (Rodentia-Muridae). Revista Brasileira de Ciências Morfológicas, v. 10, n. 1, p. 53-60, 1993.

11.HERMO, L.; OKO, R.; MORALES, C. Secretion and endocytosis in the male reproductive tract: a role in sperm maturation. International Review Cytology, v. 154, p. 105189, 1994.

12.NICANDER, L.; MALMQVIST, M. Ultrastructural observations suggesting merocrine secretion in the initial segment of the mammalian epididymis. Cell Tissue Research, v. 184, n. 4 , p. $487-490,1977$.

13. FLICKINGER, C. J. Synthesis, transport and secretion of protein in the initial segment of the mouse epididymis as studied by electron microscope radiautography. Biology of Reproduction, v. 20, n. 5, p. 1015-1030, 1979.

14. FLICKINGER, C. J. Regional differences in synthesis, intracellular transport, and secretion of protein in the mouse epididymis. Biology of Reproduction, v. 25, n. 4, p. 871-883, 1981.

15.FLICKINGER, C. J. Synthesis and secretion of glycoprotein by the epididymal epithelium. Archives of Andrology, v. 4, n. 2, p. 157-161, 1983.

16. FLICKINGER, C. J. Autoradiographic analysis of the secretory pathway for glycoprotein in principal cells of the mouse epididymis exposed to H3-fucose. Biology of Reproduction, v. 32, p. 377-389, 1985.

17.ROBAIRE, B.; HERMO, L. Efferent ducts, epididymis, and vas deferens structure, functions, and their regulation. In: KNOBIL, E.; NEILL, J. D. The physiology of reproduction. New York: Raven Press, 1988. p. 999-1080.

18.LIU, H. W.; SHANG, S. T.; CHAO, C. F.; MULLER, C. The secretion of two sperm maturation-related glycoproteins in
BALB/c mouse epididymis. Cell Tissue Research, v. 265, n. 3, p. 409-414, 1991.

19.DOMENICONI, R. F.; ORSI, A. M.; BEU, C. C. L.; FELISBINO, S. L. Morphological features of the epididymal epithelium of gerbil, Meriones unguiculatus. Tissue and Cell, v. 39, n. 1, p. 47-57, 2007.

20.ADAMALI, H. I.; HERMO, L. Apical and narrow cells are distinct cell types differing in their structure, distribution, and functions in the adult rat epididymis. Journal of Andrology, v. 17 , n. 3, p. 208-222, 1996.

21.HAMILTON, D. W. Structure and function of the epithelium lining the ductuli efferentes; ductus epididymis and ductus deferens in the rat. In: GREEP, R. O.; ASTWOOD, E. B. Handbook of physiology. Baltimore: Williams \& Wilkins, 1975. p. 259-301.

22. YEUNG, C. H.; COOPER, T. G. Study of the role of epididymal a-glucosidase in the fertility of male rats by administration of the enzyme inhibitor castanospermine. Journal of Reproduction and Fertility, v. 102, n. 2, p. 401-410, 1994.

23. GLOVER, T. D.; NICANDER, L. Some aspects of structure and function in the mammalian epididymis. Journal of Reproduction and Fertility, v. 13, p. 39-50, 1971. Supplement.

24.HOFFER, A. P.; HAMILTON, D. W.; FAWCETT, D. W. The ultrastructure of the principal cells and intraepithelial leucocytes in the initial segment of the rat epididymis. Anatomical Record, v. 175, n. 2, p. 169-202, 1973.

25.HERMO, L.; GREEN, H.; CLERMONT, Y. Golgi apparatus of epithelial principal cells of the epididymal initial segment of the rat: Structure, relationship with endoplasmic reticulum, and role in the formation of secretory vesicles. Anatomical Record, v. 229, n. 2, p. 159-176, 1991.

26.NICANDER, L.; GLOVER, T. D. Regional histology and fine structure of the epididymal duct in the golden hamster (Mesocricetus auratus). Journal of Anatomy, v. 114, pt. 3, p. 347-364, 1973.

27. NICANDER, L.; PLÖEN, L. Studies on regional fine structure and function in the rabbit epididymis. International Journal of Andrology, v. 2, n. 1/6, p. 463-481, 1979.

28. VICENTINI, C. A.; ORSI, A. M.; GREGÓRIO, E. A.; MELLO DIAS, S. Ultra-estrutura do segmento terminal do epidídimo no gato (Felis domestica). Revista Brasileira de Ciências Morfológicas, v. 2, n. 1, p. 24-31, 1985.

29. OKE, B. O.; AIRE, T. A. Ultrastructural evidence of secretion in different zones of the caput epididymis of the African giant rat (Cricetomys gambianus, Waterhouse). Archives Veterinary Medicine, v. 60, n. 4, p. 207-212, 1990.

30.ARRIGHI, S.; ROMANELLO, M. G.; DOMENEGHINI, C. Ultrastructure of epididymal epithelium in Equus caballus. Annals of Anatomy, v. 175, n. 1, p. 1-9, 1993.

31.REID, B. L.; CLELAND, K. W. The structure and function of the epididymis. I. The histology of the rat epididymis. Australian Journal o Zoology, v. 5, n. 3, p. 223-246, 1957.

32.ORSI, A. M.; VICENTINI, C. A.; MELO, V. R.; DALL PAI, V.; GREGÓRIO, E. A. Sobre a morfologia da via seminífera extra-testicular no bovino zebu (Bos indicus). II. Reexame da histologia regional do epidídimo. Ciência e Cultura, v. 36, n. 2, p. 263-268, 1984.

33. VICENTINI, C. A.; ORSI, A. M. Histologia regional do epidídimo no hamster champanha (Mesocricetus auratus). Revista Brasileira de Biologia, v. 47, n. 3, p. 277-281, 1987. 
34.SCHIMMING, B. C.; VICENTINI, C. A.; ORSI, A. M.; FRANCESCHINI-VICENTINI，I. B.; ABREU-RAYS， M. A. Regional histology of the ductus epididymidis in the dog (Canis familiaris, L.). Revista Chilena de Anatomía, v. 15, n. 1, p. 5-12, 1997.

35.VICENTINI, C. A.; ORSI, A. M.; MELLO DIAS, S.; PASSIPIERI, M.; FRANCESCHINI, I. B. Sobre a morfologia da via seminífera extratesticular no bovino zebu (Bos indicus). III. Observações sobre o epitélio epididímico. Ciência e Cultura, v. 36, n. 1, p. $1185-1188,1984$.

36.BROOKS, D. E. Epididymal function and their hormonal regulation. Australian Journal of Biological Science, v. 36, p. 205-221, 1983.

37.AMMAN, R. P.; SCHANBACHER, B. D. Physiology of the male reproduction. Journal of Animal Science, v. 57, p. 380 403, 1983. Supplement, 2.

38. AMMAN, R. P. Structure and function of the normal testis and epididymis. Journal of the American College of Toxicology, v. 8, n. 3, p. 457-471, 1989.

39. AMMAN, R. P. Physiology and endocrinology. In: McKINNON, A. O.; VOSS, J. L. Equine reproduction. Philadelphia: Lea \& Febiger, 1993. p. 658-685. 